IRA-International Journal of Management \&

Social Sciences

ISSN 2455-2267; Vol.18, Issue 01 (Q.1 2022)

Pg. no. 1-12.

IRA Academico Research

\title{
Conflict Management Mechanisms through Social Media among the Nigerian Baptist Pastors
}

\section{Adebayo Ola Afolaranmi (i)}

Peace and Conflict Studies, Lead City University, Ibadan, Nigeria.

Type of Work: Peer Reviewed.

DOl: https://dx.doi.org/10.21013/jmss.v18.n1.p1

\section{How to cite this paper:}

Afolaranmi, A. O. (2022). Conflict Management Mechanisms through Social Media among the Nigerian Baptist Pastors. IRA-International Journal of Management \& Social Sciences (ISSN 2455-2267), 18(1), 1-12. DOI: https://dx.doi.org/10.21013/jmss.v18.n1.p1

(C) IRA Academico Research.

This full-text of this paper is available under Open Access subject to a Creative Commons Attribution-NonCommercial 4.0 International License $[-\widehat{A}$ and further subject to a proper citation of its primary publication source.

Disclaimer: The scholarly papers as reviewed and published by IRA Academico Research are the views and opinions of their respective authors and are not the views or opinions of IRA Academico Research. IRA Academico Research disclaims any harm or loss caused due to the published content to any party.

IRA Academico Research is an institutional publisher member of Publishers International Linking Association Inc. (PILA-CrossRef), USA. Being an institutional signatory to the Budapest Open Access Initiative, Hungary, the content published by IRA Academico Research is available under Open Access. IRA Academico Research is also a registered content provider under Open Access Initiative Protocol for Metadata Harvesting (OAI-PMH).

This paper is peer-reviewed following IRA Academico Research's Peer Review Program[`].

Adebayo Ola Afolaranmi (iD)/0000-0001-8057-137X 


\begin{abstract}
This article aims at exploring the conflict management mechanisms through social media that the pastors of the Nigerian Baptist Convention are using in their churches. Twenty pastors were randomly and purposively selected from the pool of Baptist church pastors in the Ibadan metropolis. Five key officers of the Nigerian Baptist Convention at the national level at its headquarters were also interacted with. Each of these pastors was orally interviewed. Some documents were used to substantiate or disprove the assertions of these pastors. It was revealed during the study that church members are faced with a lot of conflicts. It was also revealed that pastors have been unconsciously using various conflict management mechanisms to resolve these conflicts. Furthermore, the study revealed that pastors have started using social media to resolve conflicts. The study, therefore, recommends that Baptist pastors in particular and other pastors, in general, should be introduced formally to more conflict management mechanisms in order to more effectively and consciously resolve conflicts among their church members. The study also recommends that pastors should be more familiar with how to use social media to manage conflicts among their church members.
\end{abstract}

Keywords: Nigerian Baptist pastors, conflicts, conflict management mechanisms, conflict resolution, social media

\title{
Introduction
}

Against the backdrop that conflict is inescapable in any given society or organization, the Nigerian Baptist pastors have deployed ways to resolve conflict among their church members. Having considered who the Nigerian Baptist pastors are and the interplay between conflict resolution and conflict management, this article explores conflict management mechanisms that the Nigerian Baptist pastors are using to resolve conflicts among their church members. With the advent and growing popularity of social media as a means of communication in this modern age, these conflict management mechanisms are interwoven with the use of social media.

\section{Methodology}

This study is a qualitative one. It is the synthesized reports of oral interview sessions with randomly selected pastors in churches in the Ibadan metropolis that are cooperating with the Nigerian Baptist Convention. The interviewed pastors were twenty pastors (fourteen males and six females) that were randomly and purposively selected from the pool of Baptist church pastors in Ibadan metropolis that are using at least one category of social media and other five key officers (three male and two female) of the Nigerian Baptist Convention at the national level at its headquarters. Some documents are analyzed to corroborate or negate the assertions of the interviewed pastors. In some cases, the identity of respondents is not disclosed because of the sensitivity of the comments they made and the confidentiality the respondents reposed in this researcher before making such comments. Since all the respondents are pastors, at times the word "pastor" or "pastors" is simply used to refer to them in this article.

\section{Conceptual Framework}

There have been various definitions and descriptions of what conflict means. Nevertheless, for this paper, conflict simply is a clash of interests, different values, opinions, needs, interests, and/or a serious disagreement or argument between two or more people that may lead to violence, war, and lack of peace. In spite of the fact that conflict management and conflict resolution are often used synonymously in many literatures, there are some distinctions between these two terminologies (Das, 2018). Both of them are two means at different sides of a field that are used to deal with the same conflicts but at different stages of these conflicts. While conflict management, Nwanmuoh, et al (2021) also referred to as "conflict regulation" is a practical way of averting conflicts, conflict resolution has to do with methods employed after a conflict has occurred (Das, 2018). Conflict management is simply the prospect of making a conflict situation better and making a relationship stronger (Olayemi, Olugbenga, and Oluokun, 2019).

Broadly speaking, conflict management is the use of resolution and inspiration methods to control the level and influence of disrupting conflict within a unit, while making use of the more positive and helpful aspects of the relationship, cooperation, and conciliation (Osisioma, 2016). There is a variation of conflict management means like "compromising, competing, avoiding, collaborating, or accommodating based on self-interest or the interests of others" (Cheng and Fisk, 2021). This variation is represented in what is known as the "Thomas Kilmann Conflict Model" as presented by Mishra and Sengupta (2021) is shown in Figure 1. 


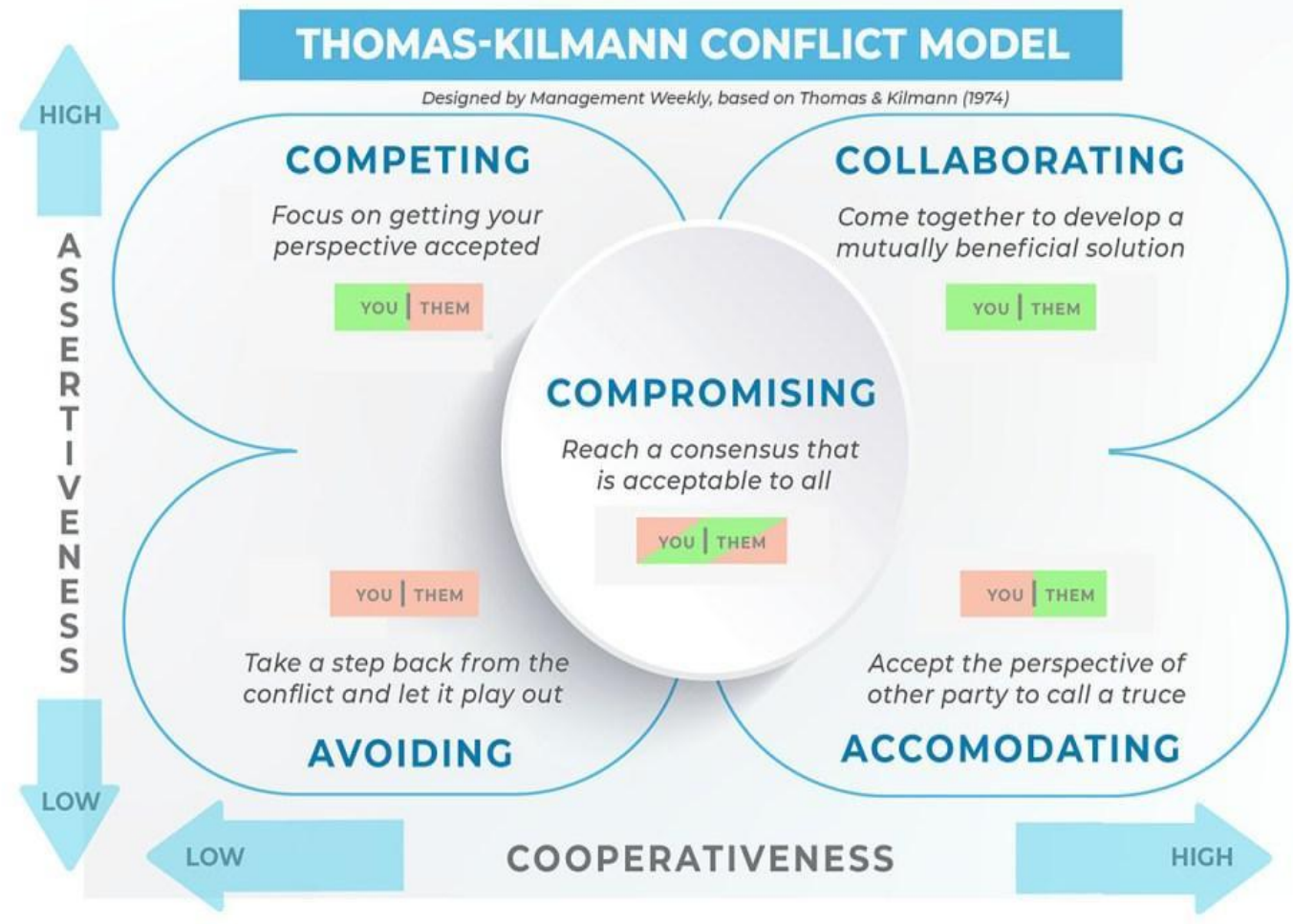

Figure 1: Thomas Kilmann Conflict Model (Mishra and Sengupta, 2021)

Four key levels of conflict management have been identified by scholars. These levels are: "intergroup, intragroup/intra-organizational, interpersonal, and intrapersonal conflicts" (Cheng and Fisk, 2021). Likewise, a scholar also identified "two sides of the conflict management coin: the side of counterterrorism, espousing exclusivity and manifested by proscription, and the side of mediation, characterized by inclusivity" (Federer, 2019).

Social media are user-based online media (websites and applications) that focus on making online communities of people who share interests and/or activities, or that have an interest in exploring the interests and activities of others. These are sorts of quasi-websites in form of forums, groups, blogs, and the likes. They are online tools that have been created to engage people, motivate and encourage them to be better people and create better livelihoods for themselves as they communicate and share information. These services are used mostly interchangeably with the term social media. Instant Messaging Apps are forms of social media that have unique ways of sharing information in form of text messages, pictures, audio, and video clips that are used with smartphones and other technological tools that support them (Afolaranmi, 2020).

Baptists are a set of Christians that form a major branch of Protestant Christianity who is distinguished by baptizing professing believers only and doing so by complete immersion. The Nigerian Baptist Convention is a group of Christians of the Baptist faith mostly in Nigeria that come together to cooperate in fulfilling the mandate of the Great Commission preaching and teaching the gospel of Jesus Christ, in taking care and in developing churches to be involved in all-inclusive ministries of evangelism, social services, and healing, and by cooperating with other Christian organizations throughout the world.

A local Baptist church pastor is a called, trained, and possibly ordained person that is "called" by the local church to be the spiritual and administrative leader of the church. This is in contrast to other pastors or ministers of the gospel who are denominational workers, missionaries/evangelists, and teachers/lecturers in Bible colleges and/or theological seminaries. In churches that practice full or partial multi-staff ministry (that is, where there is more than one full-time or part-time pastor), the head pastor (or senior pastor) is simply referred to here as the pastor while the other supporting pastors are referred to as associate pastors. These associate pastors may specifically be in charge of an aspect of the church like evangelism and missions, education, music, youth, children, and so on. 


\section{Nigerian Baptist Convention and Conflict Resolution}

The Nigerian Baptist Convention, as a faith-based organization, has been involved in many forms of conflict resolution and transformation "for a long time though the Convention does not call these forms conflict resolution or any technical term" (Akanji, 2021). Some studies have been carried out in the past to confirm this (see Afolabi, 2012 and Oludele, 2014). As admitted by almost all the pastors interviewed, most of these procedures are based on some biblical instructions.

It has been affirmed that the "Nigerian Baptist Convention in general and its local churches, in particular, have experienced different forms of conflicts. From the early history of the Convention, the dispute has been a recurring issue" (Oludele, 2014). This has made the Convention to have procedures of settling (Afolabi, 2018). The Convention recently produced a document that "clearly state procedures to follow in the discipline of an erring church or pastor and the disciplinary measure to be taken" (Nigerian Baptist Convention, 2019).

There are many beliefs and practices of the Baptists that are distinct to them (Oladeji, 2012). However, the ones briefly explained below are likely influencing how the Nigerian Baptist Convention in general and its local churches in particular, and even individual members, react to conflicts. These are:

1. Soul Competence/Religious Liberty: Baptists believe that every person, whether a believer or an unbeliever, is free to choose what he/she believes is right in the religious realm (Oladeji, 2012). Therefore, no one should be forced to assent to any belief against his will. However, this freedom is not a license to disregard the Word of God or from being accountable to God Himself. In the words of one of the founders of the earliest Baptist church in modern times, "The ... government officer [or any other officer] is not by virtue of his office to meddle with religion, or matters of conscience, to force or compel men to this or that form of religion, or doctrine..." (McBeth, 2007).

2. The Priesthood of all Believers: the Baptists believe that every believer (that is, church member) is a priest of God and may enter into His presence in prayer directly through the Great High Priest, Jesus Christ. For this reason, no other mediator is needed between God and people. This is related to belief in soul competence, but it has to do with believers in Jesus Christ only. The biblical basis for this is found in 1 Peter 2:5, 9 and Revelation 5:9, 10.

3. Congregational Polity: Baptists believe in a democratic system of administration of the church and other organizations or institutions of the church. This stems from the belief in the priesthood of believers explained above. Consequently, there is no official (or ecclesiastical) elevation in the Baptist setting (Oladeji, 2012). What is involved in these democratic processes "are careful Bible study, deliberation, and prayer with reference to the business at hand, followed by a vote of the congregation to determine the will of the majority" (Lyles, 2007).

4. Autonomy of the Local Church: a local Baptist church is an independent body accountable to the Lord Jesus Christ who is believed to be the head of the church. All human authority for governing a local Baptist church resides within the local church itself. Consequently, the church is autonomous, or self-governing. No religious chain of command outside the local church may dictate a church's beliefs or practices (Oladeji, 2012). In the words of a scholar, "There cannot be [the] autonomy of the local church without the separation of church and state, and we have separation of church and state because of soul liberty" (Ishola-Esan, 2021). However, autonomy does not mean isolation. A Baptist church may fellowship with other churches around mutual interests and in an associational or cooperative tie. Hence, a local Baptist church is expected to voluntarily cooperate with a Baptist association, a Baptist conference, the Nigerian Baptist Convention, and other ecumenical bodies like the Bible Society of Nigeria, the Christian Council of Nigeria, and the Christian Association of Nigeria. The biblical basis for this is found in Colossians 1:18; 2 Corinthians 8:1-6, 16-24; 2 John 1-4; Matthew 16:18-27.

\section{Conflict Management Mechanisms Adopted by the Nigerian Baptist Pastors}

McKay (2016) has recorded how conflict can be handled constructively and creatively. Likewise, Albert, et al (1995) have elucidated some traditional ways of resolving conflicts in Ibadan. However, whereas as there are conflicts "in every human society, the nature, analysis, and resolution of conflict had differed from society to society" (Ani, 2017) so, each respondent has his/her unique ways of resolving conflicts thereby promoting peaceful coexistence in his/her church. Figure 2 below shows some of the conflict management mechanisms by the Nigerian Baptist pastors. 


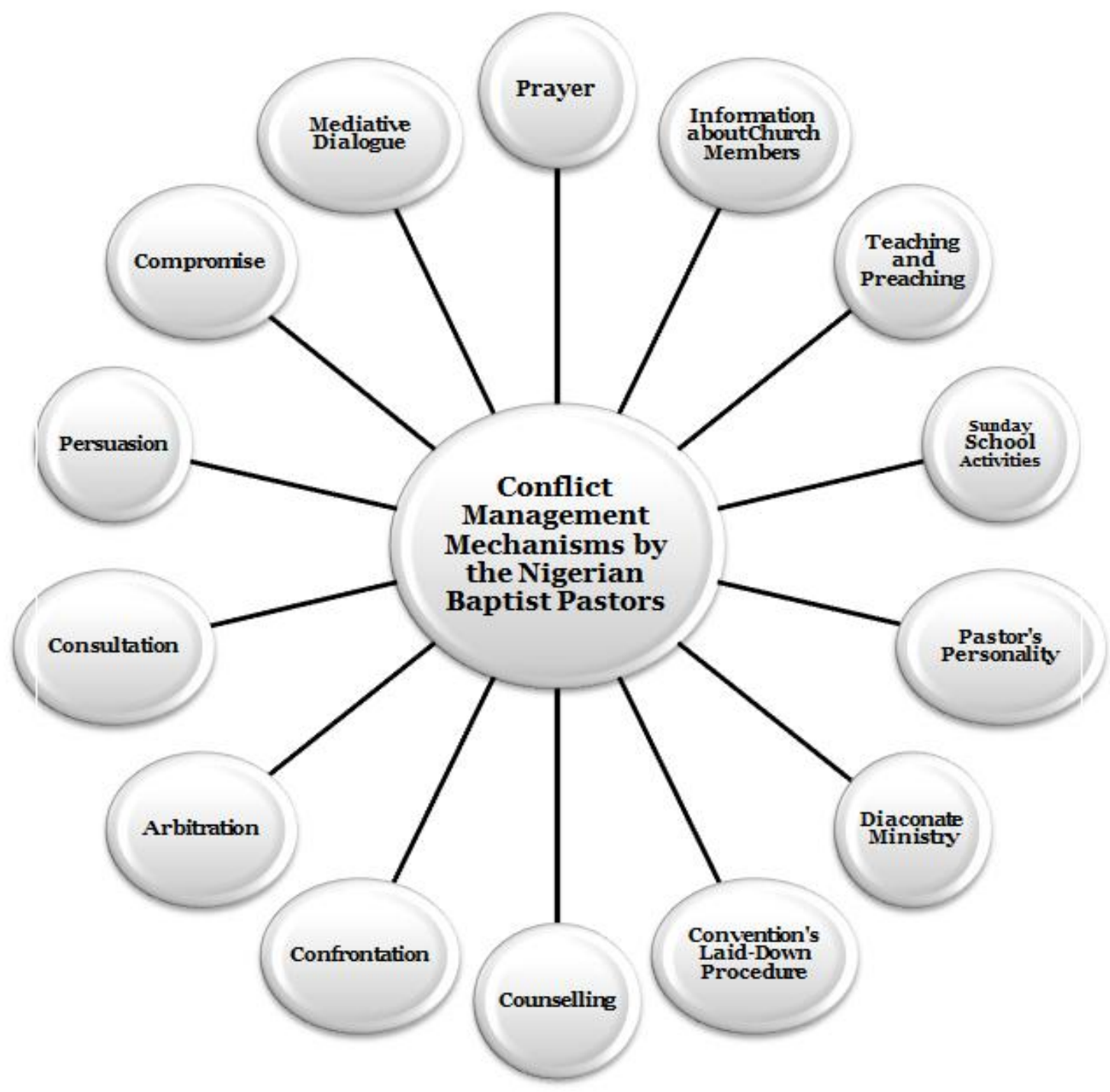

Figure 2: Conflict Management Mechanisms by the Nigerian Baptist Pastors Source: Researcher's Construct 2021

Prayer is considered by almost all the respondents as the first and the last thing to do in resolving conflicts among church members. This is because the pastors believe that only God can handle any situation successfully (Psalm 37:4-5; 127:1-2; Proverbs 3:5-7). After settling the matter with God, the pastors believe that settling any matter with human beings will not be difficult for them. After asserting the importance of prayer in the ministry of a pastor, especially during a crisis, a renowned Baptist pastor advised other pastors thus: "You and the people you lead will face all kinds of crises. As a pastor, one of the most important things you can do is help them to pray during this time" (Warren, 2020). Polk (2007) also corroborated this in a study.

As noted by Akanji (2021), every individual in the conflict is involved in resolving any conflict. Likewise, anyone can be invited to intervene or mediate in a conflict in a situation whereby the conflicting parties cannot resolve the conflict among themselves. This is against the backdrop of the congregational system of church polity in Baptist churches.

Against the background that "an accurate knowledge of a particular type of conflict will aid the diagnosis of the conflict" as observed by Nwanmuoh, et al (2021), the first means of resolving conflict is getting information about 
the conflict that will give the pastor early notification or warning about the conflict. In the words of Kurtz (1982), "The pastor needs to develop an early warning system by means of which he can recognize a situation before it flames out of control." This was considered important by one of the interviewed pastors as he asserted that he has "the phone numbers of all my church members on my phone" Fatoki (2021). This enables him to be able to contact any church member at will. The pastor takes action immediately after the conflict is known to him by contacting each party in the conflict separately to hear their sides of the story. Thereafter, he calls the parties together and attempts to resolve the conflict. If the initial attempt does not succeed, he takes further action.

Before calling any party, a respondent said that he would endeavour to identify what the conflict is all about, identify the interests in the conflict (personal, corporate, elements, source), identify the persons that are involved directly or indirectly in the conflict, and set a target (Alabi, 2021). In line with this respondent, Kurtz (1982) gave these suggestions: 1) making visible the issues involved, 2) examining the prevailing assumptions, and 3) exploring the alternatives available for controlling or resolving the conflict.

In a more elaborate way, Leas (1985) has "provided a structure for naming and identifying the different levels of intensity of conflict in a group." In the framework, he identified five levels. Level One is the Problems to Solve that is problem or issue-oriented. Level Two is Disagreement where people are more concerned with self-protection than problem-solving. Level Three is Contest where people shift their objectives to winning the argument and coming out on top. Level Four is Fight or Flight the main goal of the conflicting parties is to hurt or get rid of others or to leave if they cannot achieve this. Level Five is Intractable where the conflict is getting out of control of the conflicting parties, and the goal of contending groups is to destroy one another (Leas, 1985). Furthermore, Anyanwu (2018) gave these five steps of resolving conflicts: a) detecting the source of the conflict; b) looking beyond the incident; c) identifying how the situation could be changed; d) finding solution both conflicting parties can support, and e) making the parties agree on the found solution.

A prominent means of resolving conflicts, as indicated by the respondents, is one-on-one interaction with each of the conflicting partings. This is the initial step as identified by almost all the respondents. After the mediator has been informed about a conflicting issue, he/she finds out some salient facts about the issue. These facts may include: a) who are the active and passive actors in the issue? b) what is the origin of the issue? c) what is the present stage of the issue? d) what are the interests of each of the conflicting parties in the issue? e) and other applicable facts. The pastor will then reach out to each of the actors and/or conflicting parties and hear their personal views of the issue. He may at this stage resolve the conflict by using other means like advice, counselling, persuasion, or even confrontation by using his pastoral authority to rebuke the conflicting party (or parties) that is obvious that he is (or they are) at fault in the conflict. This latter option is referred to as arbitration where the third party takes a unilateral decision to resolve a conflict.

After one-on-one interactions with each of the contending groups, the next thing that most of the respondents do is to organize mediative dialogue sessions where the mediator will bring the conflicting parties together to resolve the conflict. Jegede (2021) advised that "...during dialogue, the parties involve are expected to control their communication style and messages." This is because, in the words of Bazezew and Neka (2017), "effective communication between individuals provides a foundation for preventing and resolving conflicts in a friendly and informal way."

One major means of resolving conflicts among church members as alluded to above is counselling. Technically, a dictionary defines pastoral counselling as "the utilization by clergy of counselling and psychotherapeutic methods to enable individuals, couples and families to handle their personal crises and problems in living constructively" (Campbell [ed.], 1987). The pastor gives counsel to the church members on diverse kinds of issues (conflict issues inclusive). Some of the respondents asserted that after hearing the views of the contending groups in any conflict issue, they (the pastors) try to counsel the parties either individually or as a group on what to do to resolve the conflict. This counselling according to the respondents is based on the teachings of the Bible and the life experiences of the pastors. Mălureanu (2014) corroborated this in a study on the meaning, relevance, and necessity of pastoral counselling. In fact, the concept of pastoral counselling is an elaborate one that is beyond the scope of this study.

In resolving a conflict of domestic violence, one respondent said that he used a video clip of a man that rough handled his wife in another country to intervene in the conflict. He first sent the video clip by WhatsApp Messenger 
to the husband in the conflict. Later, he called the man through WhatsApp Messenger to ask him about his view on the video clip. He thereafter counselled the man about the hazards of being violent when one has a disagreement with another person.

A special way that the respondents are using social media unconsciously to proactively prevent conflicts and promote peaceful coexistence is through teaching and preaching. Many of the pastors thought that one of the best proactive ways to resolve conflicts is preaching and teaching about what the Bible teaches about peaceful coexistence and against conflicts. They argued that the fact that frequent preaching and teaching have been done from the pulpit will make it easy for the mediator to mediate in any conflict. The pastor may even resort to either preaching or teaching when they are resolving conflicts.

It has to be noted, however, that the primary task of a pastor is the ministry of preaching and teaching (Chimoga, 2019). Interestingly, the popular translation of the word "pastor" in Yoruba is "Oniwaasu": one who preaches. Pastors preach every Sunday and during any service. They teach the word of God through Bible studies and other teaching avenues of the church (Chimoga, 2019). They preach and teach about peaceful coexistence and avoidance of conflicts regularly. One of the respondents even admitted that he has been using social media to do this. In relation to peacebuilding, a scholar asserted, "One of the ways Christianity has helped in securing peace in Nigeria is by appealing to the conscience of the people through ethical teachings" (Akah, 2016). In the opinion of a respondent, these proactive teachings and preaching have made resolving conflicts easier for the pastors (Oyedemi, 2021).

One of the issues that pastors stressed in their preaching and teachings on conflict resolution and peaceful coexistence as underscored by one respondent is the issue of forgiveness (Aremu, 2021). In his words, "I always lay emphasis on the issue of forgiveness in my preaching and teachings because anyone who is not ready to forgive cannot live peacefully with his neighbours" (Aremu, 2021).

Another help that pastors render the people they are making attempts to resolve their conflicts is leading the conflicting parties to reach a compromise. In the words of a respondent, "I make efforts to let the conflicting people reach a point of "give and take" (Olaleye, 2021). In this situation, "the parties accept that there are times when one must be ready to set apart individual wants and needs in preference for others in order to find a "common ground"" (Howell, 2014). Ndung'u, et al (2021), in a study, have seen compromise as a very important element in negotiation and mediative dialogue. In spite of the fact that compromise as a means of conflict resolution strategy has not been giving desirable result in resolving religious conflicts in Nigeria especially in the interfaith situation, as observed by Ogbuehi (2016), this means has been working for resolving conflicts among church members because "they share the common beliefs" (Olaleye, 2021). Afolaranmi (2021a) has emphasized this issue of "give and take" in asserting that "there is no conflict resolution strategy that can work in any situation where every parting in a conflict is insisting to have his/her way."

One of the denominational leaders who coordinate the Sunday School ministries of the Convention reiterated the importance of Sunday School in resolving conflicts and promoting peaceful coexistence among church members (Babalola, 2021). Miller (1991) defined Sunday School as "the church exercising its teaching function through church-related officers and teachers with the four-fold purpose to reach, teach, win and develop." There have been many studies on the effectiveness of Sunday School as a teaching arm of the church and the teachers/workers of Sunday School in the church (see Flake, 1922; Barnette, 1942; Miller, 1991; Towns, 2001; Babalola, 2019). There was recent research by this researcher on how Sunday School can be used as a conflict management mechanism among church members (Afolaranmi, 2021b).

One of the respondents referred to a unique way of resolving conflicts in a church setting, especially conflicts that directly involve the church pastor as a major player in the conflict (Oladimeji, 2021). This exceptional way is the act of sending another pastor from the national headquarters, state (conference) headquarters, or a Bible college to the church to serve as an "interim" pastor of the church ("Beliefs, Policies, and Practices of the Nigerian Baptist Convention"). The original church pastor will step aside for some time while the interim pastor takes charge of the church and tries to mediate in the conflict situation (Oladimeji, 2021). This is regardless of whether the pastor in the conflict was right or wrong (Akanji, 2021). The interim pastor can be in the church for "six months renewable once, making a total of one year" ("Beliefs, Policies, and Practices of the Nigerian Baptist Convention"). The scenario 
may be a situation where the church members do not agree on who to call to be the next pastor of the church at the exit of the current pastor. In order to prevent conflicts and anarchy in the church, the association or state conference may appoint an interim pastor to be in charge of the church for a period of time ("Beliefs, Policies, and Practices of the Nigerian Baptist Convention"). The effectiveness of this means of mediation varies from one church to the other. While Akanji (2021) opined that this means of resolving conflicts in the church "has worked marvellously" citing many instances, this is a subject for further study.

The onus of resolving conflicts in the church lies mainly on the church pastor. This made a respondent assert that "one who will mediate in a church setting must be empowered by God. He must be ready to sacrifice many things" (Oladimeji, 2021). Kurtz (1982) gave an important function of the pastor who is a mediator: "to divest conflict situations of their nonrealistic elements of aggressiveness." Another paramount thing in conflict management in a church is the exemplary lifestyle of the pastor. Aremu (2021) opined that "as we [pastors] are preaching and teaching about a peaceful coexistence among our church members and possible avoidance of conflicts, we have the responsibility of showing the example to our church members." He corroborated his opinion with Apostle Paul's injunction in 1 Corinthians 11:1: "Imitate me, just as I also imitate Christ." The respondent summed up this by asserting that settling a crisis will be much more difficult for a pastor that is known for causing or always being enmeshed in conflicts. A researcher substantiated this by asserting that "The lifestyle of pastors goes a long way towards influencing the spiritual life of the church"147. Abafi (2020), therefore, recommended that pastors "should be people who reflect the character of Christ. They must have a reputation beyond reproach, have spiritually mature edifying speech, have self-control and respectable conduct, be sociable, be faithful in marriage, and have skills and knowledge of the faith."

In order to effectively interfere in any conflicting situation and because "many pastors lack the skill to resolve conflict" (Onifade, 2021), Fatoki (2021) advised, "One will need to read more and acquire more skill in resolving conflicts among church members." More knowledge through reading and skill acquisition may mean undergoing special courses in conflict resolution. They may even be understudying more experienced and elderly pastors and learning from their wealth of experience in resolving conflicts.

Against the backdrop of inexperience, Onifade (2021) advised that pastors must not be afraid to seek referrals. The referral may be to other more experienced and respected pastors. This is considered an informal referral. A formal referral is when an unresolvable issue is referred to the association. The laid-down system of resolving conflicts of the Nigerian Baptist Convention encourages this. The system is that when a conflict cannot be handled locally in the church, it should be referred to the association. If the association cannot handle it, it should be referred it to the conference, and if the conference cannot handle it, refer it to the Convention. The Convention has a body that is seen as the supreme council. That is the Ministerial Board of the Convention (Afolabi, 2012).

The Ministerial Board of the Nigerian Baptist Convention emerged as a result of recurring conflicts in the churches of the Convention serving as a body to mediate in these conflicts (Afolabi, 2012). Apart from some specific roles of this board (especially on matters that have to do with pastors of the Convention) as stipulated in the constitutions of the Convention, the board is also given "the responsibility of managing and resolving conflict. The Board is involved in resolving church conflict. Whenever there is a crisis in any Baptist local church, it is the Board that will intervene in the crisis to make sure that the conflict is well managed" (Afolabi, 2012).

With this laid down system of resolving conflicts, it is very rare to see cases being taken to law courts for settlement among the members and churches of the Nigerian Baptist Convention. The biblical injunction in 1 Corinthians 6:111 also discourages litigations among the members and churches of the Nigerian Baptist Convention. Nonetheless, as asserted by Jegede (2021), "the Church that is supposed to be an epitome and shining example to the society is battling with personality clashes and court cases among themselves."

While many church members, pastors, and churches are adhering to this procedure as demonstrated in the ways pastors are resolving conflicts above, there are a handful of cases of litigation in the churches of the Convention. The occurrences of legal tussles among Christians made one of the respondents carry out his $\mathrm{PhD}$ research on finding an "alternative approach to lawsuit among believers in the church based on 1 Corinthians 6:1-11" (Ayangbile, 2016). In the research, the respondent "provided a remedy to the field findings using Paul's instructions in 1 Corinthians 6:111 which has eschatological, ethical, doctrinal and socio-political relevance to reducing lawsuit among believers" 
(Ayangbile, 2016). He concluded that "the local church should set up formidable conflict resolution body to be administered by competent people of integrity, who are just, fair and saturated with the fear of God. Such people must win the approval of the other people and be ready, to tell the truth without favouritism" (Ayangbile, 2016). As part of his recommendations, he also recommended that "the church should set up a peace and arbitration body which comprises legal practitioners and mature believers from all denominations that should be consulted by aggrieved members of sister churches to avoid embarrassment" (Ayangbile, 2016). The Nigerian Baptist Convention has such body known as the Ministerial Board that has been referred to above. This respondent added, "....instead of litigation or lawsuit, people should explore dialogue by inviting other elderly and more spiritual people to intervene in the conflict situation" (Ayangbile, 2021).

A respondent thought that the principle of autonomy of a local church as believed and practised by the Nigerian Baptist Convention and its churches at times renders the Convention powerless to exercise any authority on such uncooperating churches, pastors, and members that are not abiding by the laid-down procedure of the Convention (Afolabi, 2021). However, Madoghwe (2021) thought that the autonomy of a local is beautiful and good when the members are under the leadership of the Holy Spirit. This is against the backdrop that the church is understood to be "a congregation of believers who have been translated from the kingdom of darkness to the kingdom of light [with the infilling of the Holy Spirit]" (Oloyede, 2014). It is the opinion of Anie (2021) that this principle should be revisited. Responsible and regulated autonomy should be considered as the total autonomy of a local church can lead to disorder and anarchy in the organization (Anie, 2021).

Akanji (2021) referred to the original diaconate ministry where seven people were selected in the Early Church to resolve a conflict that arose in the budding church (see Acts 6:1-7. For more explanation on this, see Buffone, 2020). However, as discovered by Afolabi (2012) and Oludele (2014), deacons that should serve as mediators in conflicts are sometimes major actors in many conflict situations in some Nigerian Baptist churches.

\section{Conclusion and Recommendations}

Like any human organization, it has been established that churches, especially church members, of the Nigerian Baptist Convention are having inevitable conflicts among themselves. This study has shown the mechanisms that the church pastors of the Nigerian Baptist Convention to manage these conflicts. While many of these mechanisms are effective, it is evident that in some situations, they are not. The study has shown also that pastors are beginning to use social media as a means to achieve peaceful coexistence among their members. Therefore, these recommendations are given:

- Pastors should be formally trained on how to manage conflicts among their church members.

- The Nigerian Baptist Convention should review its belief and practice of autonomy of a local church to be able to control some erring churches, pastors, and members that are not abiding by the laid-down procedure of conflict management of the Convention.

- Pastors should also consciously embrace the use of social media as a means of communication in their efforts to interact with their church members and resolve any conflict among them.

\section{Areas of Further Research}

There are needs to carry out further studies on these areas as the Nigerian Baptist pastors are making efforts to engage in conflict management mechanisms among their church members:

- $\quad$ There is a need to conduct research on the extent to which the use of interim pastors to resolve church conflicts is effective.

- There is a need to conduct research on how Sunday School and other teaching arms of the church can be used as conflict management mechanisms among the church members.

- $\quad$ There is a need to conduct research on how the congregational system of government, the autonomy of a local church, and the priesthood of all church members can be used constructively as conflict management mechanisms among the church members.

- $\quad$ There is a need to conduct research on how the use of various categories of social media can enhance conflict management mechanisms among church members. 


\section{References}

[1]. "Beliefs, Policies and Practices of the Nigerian Baptist Convention." Retrieved June 19, 2021, from https://nigerianbaptist.org/wp-content/uploads/2021/05/Policies-and-Practices.pdf.

[2]. "Beliefs, Polity, Ministries, Practices, Organizations, and Heritage of Baptists." Retrieved November 6, 2019, from https://www.baptistdistinctives.org/.

[3]. "Eight Baptist Distinctives." Retrieved November 6, 2019, from http://web.engr.oregonstate.edu/ moon/oregonstatefscf/BAPTISTS.pdf.

[4]. Abafi, Alexander M. G. (2020). "Effects of Pastors' Lifestyle on Church Members: Case Study of Gyel Local Church Council of Evangelical Church Winning All." A Doctor of Ministry dissertation presented to the Faculty of Asbury Theological Seminary, Wilmore, Kentucky, USA in May 2020. Retrieved August 10, 2021, from https://place.asburyseminary.edu/cgi/viewcontent.cgi?article=2450\&context=ecommonsatsdissertations .

[5]. Afolabi, Joseph O. (2021). Interview by the researcher, Ibadan, June 1, 2021.

[6]. Afolabi, OlawaleOluwaseun (2012). Church Conflict Management in the Nigerian Baptist Convention: The Ministerial Board's Mechanism in Managing Conflict. Saarbucken: LAP LAMBERT Academic Publishing GmbH \& Co. KG. Retrieved October 12, 2019, from https://www.researchgate.net/publication/328030627_Church_Conflict_Management_in_the_Nigerian_Baptist_ Convention.

[7]. Afolabi, Oluwaseun O. (2018). “Alternative Dispute Resolution: A Tool for Managing Leadership Conflict in a Church.” Journal of Leadership Studies 12, Number 4 (2018).

[8]. Afolaranmi, Adebayo Ola (2020). "Social Media and Marital Choices: Its Implications on Contemporary Marriage”. IGWEBUIKE: An African Journal of Arts and Humanities Volume 6. No. 4. (2020). 130-153. Retrieved November 24, 2021, from https://www.igwebuikeresearchinstitute.org/journal/6.4.9.pdf.

[9]. Afolaranmi, Adebayo Ola (2021a). "Conflict Resolution Strategies in Resolving Religious Conflict in Nigeria."Academia Letters.Article 874.https://doi.org/10.20935/AL874.

[10]. Afolaranmi, Adebayo Ola (2021b). "Sunday School as a Conflict Resolution Mechanism in Churches of the Nigerian Baptist Convention.”African Social Science and Humanities Journal Volume 2, Issue 3 (2021): 185 191. Retrieved November 24, 2021, from https://journals.jfppublishers.com/asshj/article/view/65.

[11]. Akah, Josephine Ngozi (2016). "The Role of Christianity in Nigeria’s Quest for Peaceful Coexistence." BasseyAndah Journal Volume 9 (2016): 174-192.

[12]. Akanji, Israel Adelani (2021).Interview by researcher, Ibadan, November 8, 2021.

[13]. Alabi, Edward (2021). Interview by the researcher, Ibadan, May 27, 2021.

[14]. Albert, Isaac O., et al (1995). Informal Channels for Conflict Resolution in Ibadan, Nigeria. Ibadan: InstitutFrancais de Recherche en Afrique (IFRA).

[15]. Ani, Ndubuisi Christian (2017)."Re-empowering Indigenous Principles for Conflict Resolution in Africa: Implications for the African Union."Africology: The Journal of Pan African Studies Volume 10, No.9, (October 2017): 15-35. Retrieved November 24, 2021, from https://www.jpanafrican.org/docs/vol10no9/10.9-3-Ani.pdf .

[16]. Anie, Gold (2021). Interview by the researcher, Ibadan, June 3, 2021.

[17]. Anyanwu, ChristiantusIzuchukwu (2018). "Herdsmen and Farmers Conflict: An Impediment to Political Development in Nigeria." Veritas International Journal of Entrepreneurship Development (VIJED) Volume 1 Number 1 (March 2018): 175-187. Retrieved August 6, 2021, from https://www.veritas.edu.ng/entrepreneur/docs/vijed.pdf.

[18]. Aremu, Nathaniel Ajiboye (2021). Interview by the researcher, Ibadan, May 25, 2021.

[19]. Ayangbile, Moses Adelodun (2016). "Lawsuits among Believers in 1 Corinthians 6:1-11 and Its Relevance to Selected Churches in Nigeria." A PhD dissertation submitted to the Department of Biblical Studies, the Nigerian Baptist Theological Seminary, Ogbomoso in 2016.

[20]. Ayangbile,MosesAdelodun (2021). Interview by the researcher, Ibadan, May 25, 2021.

[21]. Babalola, Esther Eghe (2019). Practical Handbook for Sunday School Teachers/Workers. Ibadan: Wilsanvic Prints.

[22]. Babalola, Esther Eghe (2021). Interview by the researcher, Ibadan, May 18, 2021.

[23]. Barnette, J. N. (1942). The Place of Sunday School in Evangelism. (Nashville, TN: Sunday School Board, Southern Baptist Convention.

[24]. Bazezew, Arega and MulugetaNeka (2017)."Interpersonal Conflicts and Styles of Managing Conflicts among Students at Bahir Dar University, Ethiopia."Journal of Student Affairs in Africa Volume 5 No. 1 (2017): 27-39. DOI: 10.14426/jsaa.v5i1.2480. Retrieved June 25, 2021, from https://files.eric.ed.gov/fulltext/EJ1149513.pdf.

[25]. Buffone, GJ (2020). "The Diaconate: History \& Theology" November 2020. Retrieved November 8, 2021, from http://www.ionaschool.com/uploads/7/5/9/7/75978349/history_theology_diaconate_v7-11-2020.pdf.

[26]. Campbell, Alastair V. (ed.) (1987). Dictionary of Pastoral Care. New York: The Crossroad Publishing Company. 
[27]. Cheng, Yang and Allison Fisk (2021). "Toward a Contingency Theory of Relating Management: Exploring Organization-Public Relationships (OPRs) in Conflicts." Negotiation and Conflict Management Research (September 2021). Retrieved September 28.2021 from https://lps.library.cmu.edu/NCMR/article/id/523/.

[28]. Chimoga, Fordson Vincent (2019)."The Work of the Pastor."American Research Journal of Humanities Social Science (ARJHSS) Volume 02, Issue 02 (2019): 1-13. Retrieved June 23, 2021, from https://www.arjhss.com/wpcontent/uploads/2019/02/A220113.pdf.

[29]. Das, Tuhin K. (2018). Conflict Resolution: In Search of Peace. Independently published, December $08,2018$. Retrieved November 4, 2019, from https://www.researchgate.net/publication/329518675_conflict_resolution_in_search_of_peace.

[30]. Elmer L. Towns (2001). What Every Sunday School Teacher Should Know. Ventura, CA: Gospel Light.

[31]. Fatoki, Samuel B. (2021). Interview by the researcher, Ibadan, May 11, 2021.

[32]. Federer, J. Palmiano (2019). "We Do Negotiate with Terrorists: Navigating Liberal and Illiberal Norms in Peace Mediation." Critical Studies on Terrorism 12 (1), (2019): 19-39. https://doi.org/10.1080/17539153.2018.1472727.

[33]. Flake, Arthur (1922). Building a Standard Sunday School. Nashville, TN: Sunday School Board, Southern Baptist Convention.

[34]. Howell, Sally Erin (2014). "Conflict Management: A Literature Review and Study." Radiology Management (September/October 2014). Retrieved July 2, 2021, from http://www.ahra.org/AM/Downloads/OI/qc/RM365_p14-23_Features.pdf.

[35]. Ishola-Esan, Helen Olomu (2021). "Pastors' Leadership Behaviour and the Sustenance of Baptist Heritage in the Nigerian Baptist Convention." IAR Journal of Humanities and Cultural Studies Volume 2, Issue 4 (July 2021): 1 12. https://doi.org/10.47310/iarjahcs.2021.v02i04.001.

[36]. Jegede, Paul Oyebode (2021). "Conflict Management and Resolution in Christ Apostolic Church, Worldwide: Causes, Effects, and Solutions." International Journal of Management, Social Sciences, Peace and Conflict Studies (IJMSSPCS) Volume 4 No. 2 (June 2021): 89-99.

[37]. Kurtz, Arnold (1982). "The Pastor as a Manager of Conflict in the Church." Andrews University Seminary Studie Volume 20, No. 2 (Summer 1982): 111-126. Retrieved June 25, 2021, from https://www.andrews.edu/library/car/cardigital/Periodicals/AUSS/1982-2/1982-2-03.pdf.

[38]. Leas, Speed (1985). Moving Your Church Through Conflict. Bethesda, MD: Alban Institute.

[39]. Lyles, Ron (2007). “The Local Church”. In Baptists: History, Distinctives, Relationships. Dallas TX: BaptistWay Press.

[40]. Madoghwe, Dickson (2021). Interview by the researcher, Ibadan, July 27, 2021.

[41]. Mălureanu, Alexandru (2014). "The Meaning, the Relevance and the Necessity of Pastoral Counselling in the Conceptual Perspective.’'Teologia. Volume 60, No 3 (2014): 24-33. Retrieved July 2, 2021, from http://www.revistateologia.ro/downloads/Teologia/3_2014/Malureanu.pdf.

[42]. McBeth, H. Leon (2007). "Baptists Before 1845”. In Baptists: History, Distinctives, Relationships. Dallas TX: BaptistWay Press.

[43]. McKay, Alastair (2016). How Does the Church Handle Conflict in Its Midst, and What Challenges Does It Face in Handling Conflict Constructively? London: Bridge Builders. Retrieved June 25, 2021, from https://www.bbministries.org.uk/wpcontent/uploads/2016/04/How_does_the_church_handle_conflict_in_its_midst_BBweb.pdf.

[44]. Miller, Eveline F. (1991). Building Effective Sunday Schools: A Guide. Ibadan: Publishing Board, Nigerian Baptist Convention.

[45]. Mishra, Arindra and ShayaniSengupta (2021)."Thomas Kilmann Conflict Model."Management Weekly, May 12, 2021. Retrieved December 2, 2021, from https://managementweekly.org/thomas-kilmann-conflict-resolutionmodel/.

[46]. Ndung'u, Mary Watetu, et al (2021). "Effectiveness of Negotiation in Resolving Family Conflict: Case of Kajiado North Sub-County, Kenya." Journal of Research Innovation and Implications in Education Volume 5 No. 3 (2021): 215-224. Retrieved October 6, 2021, from https://jriiejournal.com/wpcontent/uploads/2021/09/JRIIE-5-3-021.pdf.

[47]. Nigerian Baptist Convention (2019).Handbook on Policy on Pastors and Church Conduct. Ibadan: Nigerian Baptist Convention.

[48]. Nwanmuoh, Emmanuel Ejiofo, et al (2021). "Public Relations Strategies: A Veritable Tool for Conflict Resolution, Peace Building, Democracy and National Development." International Journal of Science Academic Research Volume 02, Issue 07 (July, 2021): 1893-1897. Retrieved August 20, 2021, from https://www.scienceijsar.com/sites/default/files/article-pdf/IJSAR-0647.pdf.

[49]. Nwanmuoh, Emmanuel Ejiofo, et al (2021). "Public Relations Strategies: A Veritable Tool for Conflict Resolution, Peace Building, Democracy and National Development." International Journal of Science Academic 
Research 02, Issue 07 (July, 2021): 1893-1897. Retrieved August 20, 2021 from

https://www.scienceijsar.com/sites/default/files/article-pdf/IJSAR-0647.pdf.

[50]. Ogbuehi, F. I. (2016). "Critical appraisal of dialogue as a strategy for religious conflict resolution in Nigeria."Journal of Religion and Human Relations, Volume 8 No. 2 (2016): 167-168.

[51]. Oladeji, Moses Olatunde (2012). The People Called Baptists and their Distinctive Beliefs. Ibadan: Bounty Press Limited.

[52]. Oladimeji, Samuel O. (2021). Interview by the researcher, Ibadan, June 1, 2021.

[53]. Olaleye, Samuel AK (2021). Interview by the researcher, Ibadan, June 2, 2021.

[54]. Olayemi, Olalekan Moses, et al (2019). "A Study of Biblical Approach to Conflict Management in the Family among Postgraduate Students of Babcock University, Ilishan-Remo, Ogun State."International Journal of Humanities, Art and Social Studies (IJHAS) Volume 4, No.1 (February 2019): 27-36. Retrieved March 19, 2021, from https://airccse.com/ijhas/papers/4119ijhas03.pdf.

[55]. Oloyede, S. Akinwale (2014). "The Church, Justice and Peace: Scriptural Theological Bases" Ogbomoso Journal Of Theology (OJOT) XIX No 1 (2014): 107-122.

[56]. Oludele, OlugbadeAderemi (2014). “Clergy-Laity Conflicts over Nigerian Baptist Policies in Ogbomoso Conference, 1993-2008.” A Ph.D. thesis submitted to the Department of Religious Studies, the Faculty of Arts, University of Ibadan in 2014.

[57]. Onifade, Oluwole O. Testimony (2021). Interview by the researcher, Ibadan, May 14, 2021.

[58]. Osisioma, Benjamin Chuka (2016). "Conflict Management and Peace Building in Nigeria: Finding the Common Ground.” A paper presented at the NIM South-East Zonal Summit held at AkanuIbiam International Conference Centre, Abakaliki on September 6, 2016. Retrieved November 19, 2019, from https://www.researchgate.net/publication/308691154_conflict_management_and_peace_building_in_nigeria_fin ding_the_common_ground.

[59]. Oyedemi, Kayode (2021). Interview by the researcher, Ibadan, May 17, 2021.

[60]. Polk, Seth N. (2007). "The Twenty-First Century Pastor: His Calling, Character, and Competencies." A thesis submitted to the Faculty of Liberty Theological Seminary in 2007.

[61]. The Constitution and Regulations of the Nigerian Baptist Convention (as amended at Ibadan, Oyo State on the 1st Day of May 2014). Ibadan: Baptist Press. Also retrievable at Nigerian Baptist Convention."Constitution Nigerian Baptist Convention.”Retrieved June 14, 2021, from https://www.nigerianbaptist.org/aboutus/constitution/.

[62]. Warren, Rick. "Making Prayer a Priority in a Crisis. Pastors.com. March 17, 2020. Retrieved July 2, 2021, from https://pastors.com/making-prayer-a-priority-in-a-crisis/. 